\title{
Workplace Issues and Challenges of Women Employees
}

\author{
Dr. J. Arthi \\ Associate Professor \\ Department of Business Administration \\ School of Commerce \& Management \\ Avinashilingam Institute for Home Science \& Higher Education for Women \\ (Deemed University) \\ Coimbatore, Tamil Nadu, India
}

\begin{abstract}
Women employees are facing more challenges in their day-to-day life. Hence, to maintain their work-life balance, they are crossing many hurdles, wherein workplace issues has been one of the major challenges faced by every women employee in the world. The reason being much harassment is occurring against the women employees in all employment sectors. Even though there are more legal remedies and statutory labour welfare measures to protect women in the workplace. The foremost issues of working women globally are career progression, pay parity, harassment, child rearing and work-life balance. Hence, there is a sheer necessity to understand the aforementioned issues. The present chapter intended to analyze the workplace issues of working women as an outcome of a program conducted on legal awareness for students and working women. In furtherance, the researcher has used the data sources from the project sponsored by NCW (National Commission for Women), wherein in both gender were taken as respondents. The study included 148 respondents out of which there are working women and students from both the genders and analysed in two dimensions, one is from the perspective of working women about workplace issues and other from students' perspective to understand awareness level on workplace issues of women employees. The results showed that working women respondents have strongly agreed that workplace harassments and conflict of work-life balance are stronger issues than other challenges like shiftsystem, long working hours and gender discrimination. Also, the students (both male and female) revealed that awareness level of male students regarding workplace issues is good and opined that conflict in work-life balance and work doing night shift are predominant issues of working women and awareness of female students indicated that sexual harassment and child rearing are the major hurdles in their career progress.
\end{abstract}

Keywords: Workplace Issues, Work-Life Balance, Gender Discrimination, Work-Family Conflict, Workplace Harassment. 


\section{Introduction}

Women are backbone to a progressive society and developing nation. The percentage of women in employment is 47 percent and it is equal to their male counterparts in a country like India. However, when compared with global women employability, India had lower percentage of women workforce than other countries (World Bank, 2019) and also it is found that employability rate is equal to men but their participation in work is just 23 percent (India Skill Report, 2020). There is an upward trend in employability of Women but certain factors deter their career path. The workplace issues against woman employees are one of the critical areas, which should be concentrated by every organization as well as Government. The result of many studies about women and workplace issues indicated that gender discrimination, sexual harassment, work-life balance, biased activities, maternity leave and creche availability are major factors. The factors like low salary, job insecurity, shift work, lack of legal protection and poor working conditions are also the workplace issues faced by working women (Rajesh \& Manoj, 2016).Moreover, financial demands, cost of living and children education expenses force women to engage in a career. It is because of these demands; women are ready to work on long working hours, night shift even for less pay. Thus, running the family with happiness and successfully completing work burdens every working woman. Women are socially, economically and mentally facing many challenges to maintain the balance between their work and family. Various research studies examine the Women employees' challenges and issues in workplace, which are playing a vital role in affecting her mental health, career development and work-life balance. Keeping these aforementioned aspects in view, this chapter focuses on analysing the workplace issues of working woman and also reviews the awareness level of college students about the issues and challenges faced by women employees in their workplace.

\section{Related Literature}

Indian society supports male dominance in all major, important and challenging tasks whereas women are considered to be weak and only capable of bearing lesser work pressure at the workplace. The potential and capabilities of Indian women have always been underestimated in regard of their recruitments, salary issues and promotions. In many families, even if woman is working, her salary is given to her husband, father-in-law or elder member of the family and in doing so her independence is on the superficial level. Though woman is working, still she has to depend on somebody (Gandhi, 2014). The sexual harassments reports showed that some women do not report when it happens. Furthermore, gender discrimination at workplace has been seen in all public as well as private organizations which will create negative impact on employer. It increases the mental stress level among worker. The gender biases begin to take place at a very early stage for more Indian women. It is very difficult to accept the fact that women are also capable of working 
shoulder to shoulder with men (Channar, Abbasi \& Ujan, 2011). This is supported by a study conducted by Amol and Kumar, wherein it has been observed that women who are working in male-dominated fields experience gendered barriers that not only impede their success, but also make it difficult to combating equality within the workplace (Amol \& Kumar, 2017). This is because women are suppressed and discriminated both at workplaces and at their homes. Moreover, they are not able to give quality time to their family and hence face hurdles to maintain a balance between work life and family. This is proved by a study conducted by Jayita and Murali on working mother, which confers a woman has the responsibility of raising a child, so it necessitates her to take more than available leave options, and job security can be at risk. The significant social and personal adjustments are necessary to cope with such a situation. A working mother, especially one who has the good fortune to be able to balance her home and work enjoys the stimulation that a job or career provides. She develops the ability of raising a useful member of society and at the same time gains financial independence (Jayita \& Murali, 2009). Yet another research study analysed the challenges faced by working women at workplace, family and society in this they examine issues, impacts and remedial measures of workplaces of working women. The results indicated environmental effect and social cultural effect of women employees are enhancing the challenges of working women. Also, it suggested that by giving the three 'S', 'Strength, Safety \& Security' it will reduce their challenges (Mittal, Sharma \& Srivastava, 2015).

\section{Objectives}

$>$ To analyze the workplace challenges of women employees indifferent sectors

$>$ To review the awareness level respondents about workplace issues of women

\section{Methodology}

The entire sample respondents have been taken from participants of legal awareness programme sponsored by National Commission for Women (NCW) through convenient random sampling, wherein 148 samples are included in this study. The primary data has been collected through a structured questionnaire among 26 working women belonging to different employment sectors and 122 students from various colleges, which included 55 males and 67 females. The study adopted descriptive research design and survey method. The secondary data are collected from various online sources. The data are analyzed using simple percentages and interpreted accordingly.

\section{Results \& Discussion}

The results are discussed based on objectives to understand workplace issues and level of awareness about challenges. It includes demographic factors, level of 
awareness on what is happening in work place and perception of respondents on challenges of women at work environment.

The demographic factors are represented in cross tabulation and workplace challenges variables are calculated using simple percentage analysis based on objectives.

\section{Demographic Factors}

The demographic factors included in the study are Gender, Qualification and experience.

Table 1: Demographic Factors

\begin{tabular}{|c|c|c|c|}
\hline Particulars & Categories & $\begin{array}{c}\text { No of } \\
\text { Respondents }\end{array}$ & Total \\
\hline \multirow{3}{*}{ Group } & Student - Male & 55 & \multirow{3}{*}{148} \\
\hline & Student - Female & 67 & \\
\hline & Working women & 26 & \\
\hline \multirow{2}{*}{ Gender Distribution } & Male & 55 & \multirow{2}{*}{148} \\
\hline & Female & 93 & \\
\hline \multirow{2}{*}{ Qualification } & Undergraduate (UG) & 115 & \multirow{2}{*}{148} \\
\hline & Postgraduate (PG) & 33 & \\
\hline \multirow{4}{*}{ Experience } & Below 3 years & 3 & \multirow{4}{*}{26} \\
\hline & 3-6 years & 18 & \\
\hline & $6-10$ years & 5 & \\
\hline & Above 10 years & - & \\
\hline
\end{tabular}

The above table shows the general information about the respondents of the study. There are 55 male students, 67 female students and 26 women working women who participated in this survey. The qualification indicates that there are115 samples from undergraduate stream and 33 respondents were pursuing post graduation. In the experience category, 3 of the working women were with below 3 years working experience, 18 respondents have 3-6 years working experience and 5 from the 6-10 years category.

\section{Level of Awareness}

The awareness level on workplace issues of women employees was assessed by variables like nature of workplace issues, sharing workplace issues with family, awareness on legal remedies and availability of grievance committee in the organization. The factors given indicate to what extent the students are aware about the situation in work place and how they can be tackled. As far as the working women are concerned, they are experienced and can help to bring out the real issues 
and by giving their opinion on factors like whether they share their experience with family members, awareness on legal remedies and presence of Grievance can help to formulate strategies.

Table 2: Awareness Level on Workplace Issues of Women Employees

\begin{tabular}{|l|c|c|c|c|}
\hline \multicolumn{1}{|c|}{ Statements } & Responses & $\begin{array}{c}\text { Working } \\
\text { Women } \\
(\boldsymbol{\%})\end{array}$ & $\begin{array}{c}\text { Male } \\
\text { Students } \\
(\boldsymbol{\%})\end{array}$ & $\begin{array}{c}\text { Female } \\
\text { Students } \\
(\boldsymbol{\%})\end{array}$ \\
\hline $\begin{array}{l}\text { Nature of workplace } \\
\text { issues }\end{array}$ & Yes & 82 & 72 & 78 \\
\cline { 2 - 5 } $\begin{array}{l}\text { Share workplace } \\
\text { issues with family }\end{array}$ & Yes & 18 & 28 & 22 \\
\cline { 2 - 5 } $\begin{array}{l}\text { Aware of legal } \\
\text { remedies }\end{array}$ & No & 38 & 38 & 48 \\
\cline { 2 - 5 } & No & 21 & 20 & 52 \\
\hline \multirow{2}{*}{$\begin{array}{l}\text { Grievance cell / } \\
\text { committee in }\end{array}$} & Yes & 42 & 53 & 51 \\
\cline { 2 - 6 } & No & 58 & 47 & 49 \\
\hline
\end{tabular}

The above table shows the awareness on nature of workplace issues by the working women, male students and female students. It shows that their awareness level is high on workplace issues. Both male and female students stated that less percentage of women are sharing their workplace issues with their family. Moreover, the entire three groups specify that they are aware of legal remedies and awareness on availability of grievance cell is quite low.

\section{Perception of Respondents towards Workplace Issues of Women}

Table 3 revealed that most of the respondents could perceive the workplace issues of women employees. The male student's perception indicated conflict in work-life balance (95 percent) and work in night-shifts (93 percent) are predominant issues than other challenges. The female student's perception shows sexual harassment (97 percent) and child rearing (90 percent) are important issues than other challenges. Also, the perception of working women shows work-life balance (92 percent) and sexual harassment (88 percent) are the most affecting issues. 
Table 3: Perception of Male Students, Female Students and Working Women towards Workplace Issues of Women

\begin{tabular}{|l|c|c|c|}
\hline \multicolumn{1}{|c|}{ Statements } & $\begin{array}{c}\text { Male Student } \\
\text { Percentage (\%) }\end{array}$ & $\begin{array}{c}\text { Female Student } \\
\text { Percentage (\%) }\end{array}$ & $\begin{array}{c}\text { Working } \\
\text { Women } \\
\text { Percentage } \\
(\%)\end{array}$ \\
\hline Biased Treatment & 64 & 78 & 69 \\
\hline $\begin{array}{l}\text { Male Domination at } \\
\text { Workplace }\end{array}$ & 51 & 88 & 62 \\
\hline $\begin{array}{l}\text { Conflict In Work-Life } \\
\text { Balance }\end{array}$ & 95 & 89 & 92 \\
\hline $\begin{array}{l}\text { Gender Bias } \\
\text { Discrimination in } \\
\text { Promoting }\end{array}$ & 82 & 82 & 58 \\
\hline Target Completion Time & 73 & 79 & 73 \\
\hline Long Working Hours & 55 & 67 & 62 \\
\hline Sexual Harassment & 91 & 97 & 88 \\
\hline Child Rearing & 87 & 90 & 85 \\
\hline Work Pressure & 82 & 87 & 73 \\
\hline Work in Night-Shift & 93 & 84 & 65 \\
\hline
\end{tabular}

The following points portray the consolidated view of result analysis:

1. The demographic variables of the respondents in gender wise distribution showed that there are 55 male respondents and 93 female respondents which include 26 working women. Also, 115 are undergraduates and 33 respondents with post graduate qualification.

2. Among the three groups of respondents, majority of the respondents are aware about the workplace issues of women employees.

3. It has been observed that male students' point of view indicated that conflict in work life balance and working on night shift are the top issues for women employees. On the other hand the perception of the female student shows that sexual harassment and child rearing are the predominant challenges of women employees. The result of working women indicates that the work life balance and sexual harassment are the main issues faced by every women employee in their work place.

The results have showed perception of male students, female students and working women towards workplace issues of women employees. The variables like biased treatment of women employees, male domination at workplace, conflict in work-life balance, child rearing, sexual harassment, working hours and shift timings are included. Moreover, from the issues listed, the student respondents responded based 
on hearsay perceptions and working women have shared their real time experiences at workplaces.

Even though there are several measures taken by government towards curtailing such discriminative practices but, in reality women are the sufferers. However, still women hit the glass ceiling to prove them and occupy deserving positions in their career. Furthermore, in order to understand whether both gender of students could perceive issues that affect women employees the study focused on important aspects at their workplaces. Also, it is known from the global reports that work life balance, gender bias in promotion and pay, harassment and child rearing are viewed as vital issues that hampers women's career progression. Thus, it is quite evidential that non-inclusive workplace issues do exist, wherein women are often denied of equal opportunities and have not fully recognized their efforts. This in turn leads to failure of achieving the overall vision of many organizations.

\section{Suggestions}

$>$ Family-friendly policies can be introduced into company's framework to help them in balancing their work and life.

$>$ The career progression of women to be taken care in terms of payment and promotions so that any kind of discrimination shall be avoided.

$>$ The night shift employees to have good working environment ensuring better health and safety.

$>$ Workplace flexibility might be given like, paid family leave, child care allowances, timing of work, etc.

Gender neutral policies needs to be introduced to re-orient workplace culture.

$>$ A special committee to monitor gender bias in terms of pay and promotion of women employees and enforce workplaces strictly towards safe working environment.

\section{Conclusion}

This research chapter has addressed on the issues and challenges of working women and awareness level of all respondents. The results revealed that sexual harassment and conflict in work-life balance are dominant factors than other issues like child rearing, gender discrimination, long working hours etc. The suggestion is to add knowledge, promote right skills and enhance positive attitude towards boosting selfconfidence level to overcome the challenges in workplace. Moreover, the counselling to women employees and various programs may be conducted for creating legal awareness about women rights, which will help every woman to break invisible glass ceiling at workplace. 


\section{References}

Amol, P. \& Kumar, A. (2017). Problems Faced by Working Women Employees in BPO Sector, North Asian International Research Journal of Social Science \& Humanities. Vol.3, No.8, pp.178-186.

Channar, Z. A., Abbasi, Z. \& Ujan, I. A. (2011).Gender Discrimination in Workforce and its Impact on the Employees, Pakistan Journal of Commerce and Social Sciences, Vol.5, No.1, pp.177-191.

Gandhi, J. (2014). Challenges Faced by Working Women in India, Indian - Proud 2B Indian, $2^{\text {nd }}$ March 2014.

India Skills Report. (2020). Reimagining India's Talent Landscape for a \$5T Economy, Confederation of Indian Industry \& Taggd, Wheebox, Gurugram, Haryana, pp.1-88.

Jayita, P. \& Murali, P. (2009). Working Mothers: How Much Working, How Much Mothers, and Where Is the Womanhood? Mens Sana Manographs, Vol.7, No.1, pp.63-79.

Mittal, S., Sharma, S. \& Srivastava, P. (2015). Challenges Faced By Working Women At Workplace, Family and Society - Its Major Issues, Impact and Remedial Measures, International Journal of Research in Social Sciences and Humanities, Vol.5, No.2, pp.64-77.

Rajesh, S. \& Manoj, P. K. (2016). Women Employee Work Life and Challenges to Industrial Relations: Evidences from North Kerala, International Journal of Computational Engineering and Management, Vol.3, No.4, pp.1-8.

World Bank. (2019). Feature Story: Working for Women in India, $8^{\text {th }}$ March 2019.

\section{Webliography}

India Skill Report (2020): https://wheebox.com/assets/pdf/ISR_Report_2020.pdf http://www.proud2bindian.com/society/challenges-faced-by-working-women-inindia/

https://www.worldbank.org/en/news/feature/2019/03/08/working-for-women-inindia 